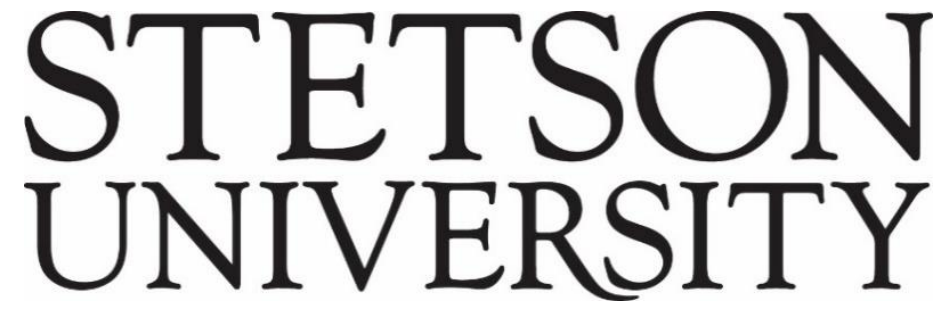

Voices of Reform: Educational Research to Inform and Reform

Volume $3 \bullet$ Issue $1 \bullet$ Article 2

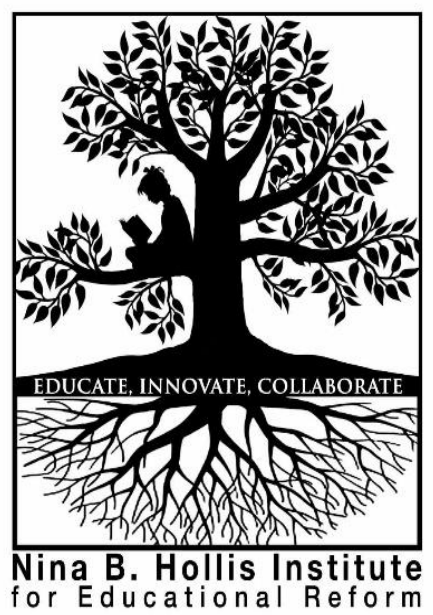

May 2020

\title{
More Alike than Not: Educational Leadership in K-12 and Higher Education: An Exploratory Study
}

Cheryl Evans

University of Central Oklahoma

Michaela Grandstaff

University of Central Oklahoma

Mike Nelson

University of Central Oklahoma

Ed Cunliff

University of Central Oklahoma

Follow this and additional works at: http://www.voicesofreform.com

Recommended Citation

Evans, C., Grandstaff, M., Nelson, M., \& Cunliff, E. (2020). More alike than not: Educational leadership in K-12 and higher education: An exploratory study. Voices of Reform, 3(1), 35-54. Retrieved from

https://www.voicesofreform.com/article/12771-more-alike-than-not-educational-leadership-in-k-12-and-higher-

education-an-exploratory-study doi: 10.32623/3.00004

http://dx.doi.org/10.32623/3.00004

Revisions

Submission date: January $2^{\text {nd }}, 2020$

$1^{\text {st }}$ Revision: February $19^{\text {th }}, 2020$

Acceptance: March $15^{\text {th }}, 2020$

Publication date: May $1^{\text {st }}, 2020$ 


\title{
More Alike than Not: Educational Leadership in K-12 and Higher Education: An Exploratory Study
}

\author{
Cheryl Evans ${ }^{1}$ \\ Michaela Grandstaff ${ }^{2}$ \\ Ed Cunliff ${ }^{3}$ \\ Mike Nelson ${ }^{4}$
}

${ }^{1}$ College of Education and Professional Studies

University of Central Oklahoma, United States

cevans20@uco.edu

${ }^{2}$ College of Education and Professional Studies

University of Central Oklahoma, United States

mgrandstaff@uco.edu

${ }^{3}$ College of Education and Professional Studies University of Central Oklahoma, United States mnelson15@uco.edu

${ }^{4}$ College of Education and Professional Studies University of Central Oklahoma, United States ecunliff@uco.edu 


\begin{abstract}
This research is intended to explore the limited study of leadership development across three areas of educational leaders: K-12, higher education professional (HE-P) (not in academics), and higher education academic leaders (HE-A). Background: Educational leaders from these three different groups are often viewed and treated separately, both in areas of research and practice. Methodology: A brief electronic survey was sent to over 600 educational leaders equally distributed across these three areas. Findings: There was noteworthy congruence in terms of the leadership theories utilized across the groupings, but differences in terms of where they received much of their professional education regarding leadership. Future Research: This study raises questions regarding efficacy of professional development approaches, the value of leadership development per se, and the potential value of bringing together the three groups in professional development activities as a means of forging a more seamless system for students.
\end{abstract}

\title{
Keywords
}

Leadership, higher education, K-12, professional leader development, educational leadership

\section{Introduction}

As research questions were developed for this study, the published research on leadership theories, and professional development for K-12, HE-A, and HE-P, were reviewed and analyzed in order to include those theories in the research questions. The literature provided the information regarding leadership theories participants would be familiar with as well as a sense of the type of programs in which leaders functioned

Accountability and the call for education reform have made leadership important in most educational fields. Rapid changes experienced in the internal and external environments of organizations have made the implementation of more efficient and effective leadership styles in organizations compulsory (Bass \& Bass, 2008; Burns, 1978; Drucker, 1988; Kotter, 2001: Yukl, 2008). When considered from this point of view, adaptation to the changing management and social structures is a necessity for educational leaders in all areas.

"In a recent research report released by the Organization for Economic Cooperation and Development (OECD) that studied education leadership in 22 nations, school leadership improvement was described as a worldwide challenge" (Pont, Nusche, \& Moorman, 2008, p. 27). Bustamante and Combs (2011) contribute to the research and were focused primarily on K-12 educational leaders and reference lack of preparation programs that addressed important issues such as recruitment of quality candidates, lack of collaborative relations with higher education faculty, and curriculum that does not address the current environment.

Similarly, Reeves and Berry (2009) note that by the late 1950's K-12 administration had evolved to the point where the bachelor's degree was accepted as a minimum for administrative certification, and in some states, a master's degree was required.

While these issues were recognized in the K-12 preparation and continuing development, there was little or no preparation for higher education academic leaders. 
This rising interest in leadership and continuous learning was paralleled by an increase in the number and type of leadership theories. These leadership theories provide the foundation for successful leadership skills. Burns (2003), and Bass (1997) examined the concept of leadership under two main titles, transactional and transformational leadership. More traditional leadership styles, transactional leadership acts under the principle of rewarding and involves mutual exchange between leadership and followers (Bass, et al., 2003; Yukl, 1989). In transformational leadership, leaders establish a link between himself/herself and followers/employees, becomes a role-model for them, encourages them to work willingly beyond their performance, acts with team spirit, makes efforts to realize the organizational goals in unity, constantly follows innovations, changes and developments, keeps the organization full and alive under fierce competition and enables the organization to get closer to success (Avolio, et al., 1999; Bass, 1997; MacKenzie, et al., 1987; Yukl, 1989 ).

Building on the works of early theorists, researchers and writers have created new approaches to school leadership (Bass, 1998; Bennis 1995b; Bolman \& Deal, 2003; Bowers, 1977; Covey, 1989; Dufour \& Eaker, 1998; Dufour, et al, 2006; Fullan, 1993; Gardner, 1993; Green, 2013; Lashway, 1999; Lezotte, 1997; Manz \& Sims, 1989; Marzano, et al., 2005; Senge, 1990; Sergiovanni, 1994, 1996). The contemporary works of these researchers and writers offered a line of reasoning that, in addition to being concerned with task completion, effective school leaders should express a concern for people because an individual cannot mandate what matters (Fullan, 1993). Leadership effectiveness lies in the balance between the desired results and the leader's ability to produce the desired results (Bowers, 1977; Covey, 1989; Halpin, 2007).

Multiple studies report that school principals have needed to examine the transformational leadership style in the formation of a school culture in which individual differences of students would be considered. Great effort would be made for the development of facilities and capabilities and students with high academic and personal achievements would be educated by creating healthy school climates (Bogler, 2001; Decker, 1989; DiPaola \& Tschannen-Moran, 2001; DiPaola \& Hoy, 2005; Geijsel, et al., 2002; Leithwood, 1992; Leithwood, et al., 1996; Leithwood \& Jantazi, 2006; Miller, 2001; Pounder, Ogawa, \& Adams, 1995; Reeves, 2006).

The primary focus for most K-12 school leaders is the human element and the involvement of individuals and groups in leading a school organization (Green, 2017). Leadership principles should apply to most, if not all, stakeholders. Teachers, students, parents, and other stakeholders have to feel a sense of personal dignity and purpose regarding their involvement with the school (Dufour \& Eaker, 1998). Stakeholders gain confidence, experience, fulfillment, build selfefficiency and commit to organization goal attainment (Bennis, 1995a; Dufour \& Eaker, 1998; Fullan, 2002). Higher education leaders should also have this primary focus, along with the leadership development that emphasizes this focus.

When looking at K-12 leaders, Green (2017) explains that contemporary researchers, writers, and organizations proposed that 21st-century school leaders should be instructional leaders who have a vision shared by stakeholders (Covey, 2013; Fullan 1999; The Wallace Foundation, 2013). Aspiring and practicing K-12 school leaders look to Bennis (1995), who proposes that leaders should have four competencies: the ability to manage meaning, trust, attention, and self. They can 
then use these competencies to ensure that the organization has purpose and structure, offering a sufficient amount of freedom to their followers. This combination allows educational leaders to experience success. Green (2017) points out that more importantly, these competencies inform educational leaders of processes and procedures that can be used to promote the well-being of every student.

The focus of $21^{\text {st }}$-century K-12 school leaders is on principle-centered leadership, fair process, shared governance, relationship building, and organizations that consist of a community of learners (Green, 2017). The theories of the past underpin what current writers and researchers characterize as facilitative leadership, participatory governance, servant leadership, and site-based management. Also included, are distributive leadership, collaborative dialogue, teaming, empowerment, learning communities, and shared governance (Green, 2013).

Black, Martin, and Danzig (2014) interviewed 30 principals from Minnesota regarding continuing professional development during their careers. These research study participants said that coordinated practices related to continued professional development were very much needed. These principals felt isolated and on their own to find the kinds of training needed to be successful as a leader. The leaders from the metropolitan areas appeared to have more opportunities and funding for professional development opportunities than rural principals. As a group, the principals were not aware of on-going collaborative efforts among school districts, universities, agencies, or professional associations, to meet their professional development needs. They were particularly critical of a "one size fits all" mentality of some of the professional development that they had experienced. The principals expressed needs related to specific skills associated with leading schools with diverse student population, working in English Language Learning communities in which languages other than English were spoken at home, and challenges raised by diversity, such as increasing social cohesion and relationships among students in schools (Black, Martin, \& Danzig, 2014).

The development of K-12 standards and accountability mechanisms, the assessment of K-12 schools, principals, teachers, and students, and shifting college admissions policies are just a few of the many areas of reform activity sweeping the nation. Little effort has been made to coordinate reform systemically across educational levels, including leadership development, in order to improve academic opportunities and the chances of success throughout students' entire educational lives.

The roles, responsibilities, and accountability of K-12 leaders has been changing due to the dramatic shift of thinking about educational leadership in the schools. This change in thinking has seen the emergence of leadership standards, which determine whether graduates from college and university preparation programs are prepared to practice the art of leadership in the K-12 setting. Green (2017) noted that the leadership standards, competencies, and accountability movement is calling for school leaders to measure the extent to which they fulfill their roles and execute their responsibilities. This paradigm shift on school leadership has redefined the roles and responsibilities of school leaders (Green). If Higher Education Leaders went through a more formal leadership development program, it would then be possible and helpful to provide measure for accountability. 
The Interstate School Leaders Licensure Consortium (ISLLC) was formed to establish national standards for models of leadership deemed appropriate for K-12 leaders (Davis et. al., 2005). These standards provide a set of common expectations for the knowledge, skills, and dispositions of school leaders grounded in principles of powerful teaching and learning (Davis et, al.). ISLLC standards have gained acceptance and have been influential in the design of administrator preparation programs across the nation. While there are many empirical reports of what effective principals do, many questions remain about the relative importance of different leadership strategies on student achievement (Davis et. al.).

Leadership theories, models, and strategies in educational administration have been the focus of research and opinion for quite some time. Most recently, Kezar and Holcombe (2017) studied the issues facing today's higher education leadership and suggested that the current state of significant change in higher education has led in the growing attention to leadership traits required to guide campuses successfully and a growing concern that existing approaches to leadership are ineffective. The Bureau of Labor Statistics identifies higher education leadership as a growth area that will likely increase ten percent between 2016 and 2026 (Bureau of Labor Statistics [BLS], 2018). Master's as well as doctoral level programs in higher educational leadership have grown in the U.S. to address some of this concern.

The researchers reviewed the literature on leadership theories in the sectors of K-12, HE-A, and HE-P, to uncover any of the relationship in the theories, but there was an included analysis of literature that led to more recent leadership theories that survey participants would be interested in learning more about. As more recent leadership theories were identified to use in the study, an analysis of the leadership development provided for K-12, HE-A, and HE-P, was needed to examine the possible similarities and differences, if any, of leadership development.

Most institutions of higher education paid little attention to either the preparation of academic department leaders at that level or their succession into the position (Sessa \& Taylor, 2000). The majority of individuals who became department chairs have neither prior leadership preparation nor a clear understanding of what the job entails (Ely, 1994; Jackson, 1996). Gmelch (2000) found that only $3 \%$ of more than 2,000 academic leaders surveyed in U.S. national studies between 1990 and 2000, had any type of leadership preparation.

$\mathrm{HE}$ and $\mathrm{K}-12$, have been viewed as unconnected systems and structurally separate in many state systems. The educational preparation and professional development of leaders from these two systems occurs separately and the similarities and differences of their needs with few research studies completed. What might be the benefits and possible efficiencies of sharing the preparation and professional development? Leaders in K-12 go through a prescribed process that leads to certification as principals or superintendents. Higher education leaders have no parallel path in terms of certifications or state mandates.

Research conducted by Metheney-Fisher (2012), sought to determine how higher education leaders learned to lead. Utilizing 118 completed surveys and 20 interviews, the author found that learning to be a leader in higher education has historically not been a structured process. Her research sought to better understand how leaders in higher education learn to lead and what 
influence experience, professional development, mentoring and critical incidents played in the learning process. "Leadership is widely accepted as a critical factor to the success, mediocrity, or failure of an organization (Collins, 2001; March \& Weil, 2005; Northouse, 2015). Success is no less the case in higher education, where the impact of leaders and leadership is critical to academic and administrative effectiveness" (Collins, 2001, p. 96).

Gigliotti and Ruben (2017) are adamant in the assertion that, "Leadership in higher education administration is significant, yet as others suggest the opportunities are not that accessible"(p.96). Bisbee (2007) surveyed provosts, academic deans, and other mid-level academic leaders at 16 land grant universities. She found that only a quarter of the respondents received some type of leadership training and $70 \%$ felt job experience was the most valuable type of leadership development. Only half of the respondents felt well prepared for their current position and leadership in general.

Formal education, rather than mentoring and on the job training (OJT), is a strong need as suggested by Gigliotti and Ruben (2017), "Considering the scope and scale of challenges facing leaders in higher education, there is a perceived scarcity of formal education programs available to those with academic or administrative leadership responsibilities" (p. 98).

Gmelch and Buller (2015) offer a strong statement regarding the often relied upon leadership workshops and conferences aimed at higher education leaders. "...if we assume that it takes ten to twenty years for a highly intelligent person to become an expert in an academic discipline, why do we assume that we can train academic leaders in a three-day workshop?" (p. 68).

Ruben, De Lisi, and Gigliotti (2017) offer insight into the reason for a shortage of formal education for higher education leaders. They suggest the shortage is "due in part to the perception that subject matter expertise and experience are the primary ingredients necessary to provide effective leadership in higher education. We are currently witnessing a change in attitude on this topic as these traditions change, and as an increasing number of colleges and universities as a positive identify the need to focus greater attention on leadership development" (Ruben, et.al., 2017, p. 98).

In the work mentioned earlier by Reeves and Berry (2009), the collaboration between higher education as a provider to K-12 developing leaders was viewed as a process: "As more universities offered educational administration, the curriculum evolved and expanded to include in-depth study of organization, finance, instruction, personnel, school law, and content related to leading and managing schools" (Reeves \& Berry, p. 3). Ruben (2004) suggested another way to consider this idea: “ ... we must devote more attention to leadership issues within the academy; this can begin by applying the same continuing education philosophy and resources to leadership development for internal groups that we so enthusiastically advocate for others outside the academy" (p.23).

Unit leaders in higher education need to improve their career competencies in order to perform successfully in their professional role. To improve their career competencies, unit leaders may choose to participate in professional development experiences (Nicoll \& Edwards, 2012). However, compared to other industries, leaders in higher education devote a scant amount of time, energy, and resources to professional development (Ruben, 2004). Bacheler (2015) conducted a qualitative study to examine the effects of professional development experiences on a small 
number (10) of Continuing Higher Education Unit Leaders (CHEULs). The CHEULs were selected based on their role as a senior-level officer on a campus who manages and supervises a continuing higher education unit. Through semi-structured interviews using open-ended questions concerning their professional development experiences, Bacheler (2015) found six emergent themes. One of those themes, Gaps in Professional Development Experiences, indicated some experiences provided content that was too generic and focused mostly on broad-spectrum issues in higher education while others presented content that was outdated or repetitive (Bacheler, 2015).

When Bacheler (2015) discovered the lack of research in higher education leadership development, an intriguing curiosity arose about the HE-A, and HE-P leaders, and the type of leadership development that was provided for them to successfully complete their jobs, and leadership goals. The types of leadership development that were included in the study included structured programs, and/or self-directed leadership development that would include reading scholarly books, articles, online, various workshops, and/or networking with other HE-A, and HE-P leaders.

Finally, literature on the congruence of leadership theories used by leaders in K-12 and higher education provided the needed information about types of leadership and the need for more attention to be given to leadership development in higher education. This research study is a step in the right direction that can make a needed change for current and future K-12 leaders, as well as HE-A, and HE-P leaders.

\section{Methodology}

This quantitative study was designed to uncover similarities and differences between leaders in K12, HE-A, and HE-P pertaining to their theoretical foundations, methods of leadership development, and issues for further learning that could contribute to K-12, HE-A, and HE-P leadership practice. The current study specifically focused on educational leaders in the Oklahoma City metropolitan area. This initial study was conducted in a metropolitan area with the intent to expand the study to other metropolitan areas that have large public-school systems as well as public higher education institutions. All university procedures were followed, and approval of the research was received through the Institutional Review Board (IRB), at the University of Central Oklahoma (UCO).

\section{Participant Information}

For the purpose of this study, leaders were defined as individuals who have a formal administrative role. This study included a balanced cross-section of HE-A, HE-P, and K-12 leaders. The sample was purposive and represented the number of leaders identified in higher education, and an approximately equal number in K-12. There were 142 participants $(N=142)$ that met the following criteria to be included in the sample:

(1) Currently employed in a full-time administrative role in either a K-12 or Higher Education setting;

(2) Work in the Oklahoma City metropolitan area; and

(3) Work in the public sector of education. 
Leaders, as defined here, were identifiable in the K-12 system as principals, assistant principals or superintendents. Individuals in these K-12 roles are plentiful, but the number of higher education institutions and administrative roles is more limited. The researchers, therefore, began by reviewing and collecting names of individuals identified with leadership roles on metropolitan, public university web sites. The web sites were searched for those in HE-A with titles such as Dean, Vice President of Academic Affairs and Department Chair. Within the category of HE-P the search was conducted for Directors, Executive Directors and Vice Presidents of recognized non-academic roles. Once these roles were selected, an equal number of K-12 leaders were randomly identified using a publicly available listing available through the Oklahoma State Department of Education. The total number was 748 educational leaders across K-12, HE-A, and HE-P leaders.

Names, titles and email addresses were obtained by searching public metropolitan university Internet websites, school district websites, Google, and the Oklahoma State Department of Education website which contained an administrative email list-serve. All emails were available to the public.

\section{Survey Development}

The survey addressed the major themes of the research questions. A list of 20 different leadership theories was developed from theories identified in several educational leadership texts. Theories were then presented to graduate students in educational leadership classes who were professionals in the field already. Theories were reviewed by the researchers using a focus group approach and reduced to seven generally recognized leadership theories. To enhance validity of the survey instrument, the graduate leadership students also reviewed the descriptions of those theories used in the survey (see Appendix B). These brief descriptions of the theories were included in the survey to enhance reliability of responses. 
Table 1: Leadership theories, models, or styles and definitions selected for survey

\begin{tabular}{|l|l|}
\hline \multicolumn{1}{|c|}{$\begin{array}{c}\text { Leadership Theories, } \\
\text { Models, or Styles }\end{array}$} & \multicolumn{1}{|c|}{ Definition } \\
\hline Situational/Contingency & Choice of leadership style \\
\hline Transformational & Leadership that effects change \\
\hline Servant & Leaders focus on followers' needs \\
\hline Transactional & $\begin{array}{l}\text { Leaders promote compliance of followers } \\
\text { through rewards and punishments }\end{array}$ \\
\hline Authoritative/Autocratic & $\begin{array}{l}\text { Leaders perceive followers as needing } \\
\text { direction }\end{array}$ \\
\hline Distributive & Multiple leaders \\
\hline Democratic & Shared leadership \\
\hline
\end{tabular}

The survey was then reviewed by scholarly research professors from the University of Central Oklahoma (UCO) to evaluate the wording, key phrases, and grammar. Suggestions were given on how to improve the survey, and the instrument was revised. Suggestions included types of questions and simplifying word and/or phrases used in the questions. The final survey instrument was again reviewed by professionals in the Educational Leadership classes to ensure validity and readability. The modified instrument was used for the official study. The final instrument contained five questions requiring no more than ten minutes to complete.

\section{Survey Process}

Surveys can be used to collect data about characteristics, experiences, and opinions in relation to participants (Gall, et al., 1996). As this study was considered by the researchers to be the initial part of an extended study, the survey process was ideal. All survey data were reported and disseminated as aggregate data.

An electronic survey using Qualtrics, an online software survey tool, was used to collect data. Standard procedures of identity protection were followed as delineated by the Institutional Review Board. Seven hundred and forty-eight surveys were emailed but one hundred fourteen came back as undeliverable. Six hundred and thirty-four surveys were successfully emailed and of those 142 completed responses were received for a return rate of $22.4 \%$. The majority of responses occurred within the first week after dissemination, though there were additional responses after a reminder was emailed at the end of two weeks.

\section{Data Analysis}

The survey system, Qualtrics, provided simple analysis of the data, but the raw data were exported to Excel for further analysis. The study had been designed as a simple quantitative study and was 
not intended to go beyond descriptive analysis at this point in time. Charts were developed that responded to each of the research questions.

Interpretation of the data was done initially by one of the researchers; each of the other researchers then reviewed the data, interpreted the data individually, and convergent themes were discussed, and differing perspectives were considered. This form of inter-rater reliability approximates the claim of Rossman (1999) "Reading, reading, and reading once more through the data forces the researcher to become familiar with those data in intimate ways" (p.153). While further statistical analysis could have been possible, it was determined that for the purposes of this study a descriptive analysis would provide appropriate insight into the data.

\section{Results}

The initial participant list included $57 \mathrm{~K}-12$ leaders, 43 HE-A leaders, and 42 HE-P leaders One hundred forty-two returns equated to a $22.4 \%$ return rate, which were well distributed in terms of the three leadership areas as well as gender. The number of female respondents was slightly higher, $80(56 \%)$, than their male counterparts, $62(44 \%)$.

Table 2: Respondents by educational area

\begin{tabular}{|l|l|l|}
\hline \multicolumn{1}{|c|}{ Leadership Role } & \multicolumn{1}{c|}{$\#$} & \multicolumn{1}{c|}{$\%$} \\
\hline K-12 & 57 & $40 \%$ \\
\hline HE-A & 43 & $30 \%$ \\
\hline HE-P & 42 & $30 \%$ \\
\hline Total & 142 & $100 \%$ \\
\hline
\end{tabular}

\section{Most Utilized Leadership Theories, Models, or Styles}

Participants were asked to rank the top three leadership theories that they used the most from a list of seven theories including: situational/contingency, transactional, authoritative, distributive, democratic/autocratic, servant leadership, or transformational leadership. Servant leadership (Greenleaf, 1977) was identified as the most utilized theory amongst all participant groups (HE A, HE - P, K-12). The servant leadership theory appeared as early as 1970 and is probably one of the best known in the field of leadership studies (Greenleaf, 1977). It may be suggested that leaders in the field of education tend to identify in general as servants, committed to the cause of education, and it may be a logical finding to discover that it is the most utilized amongst these leaders (Greenleaf, 1977). Note that the next closest theory, fell more than $30 \%$ points below in terms of total overall rankings (transformational). 
Table 3: Number one ranking of theories used most often

\begin{tabular}{|l|l|l|l|l|}
\hline \multicolumn{1}{|c|}{ Theories } & \multicolumn{1}{|c|}{$\begin{array}{c}\text { K-12 } \\
\mathbf{\%}\end{array}$} & $\begin{array}{c}\text { HE-A } \\
\mathbf{\%}\end{array}$ & $\begin{array}{c}\text { HE-P } \\
\boldsymbol{\%}\end{array}$ & $\begin{array}{c}\text { Total } \\
\boldsymbol{\%}\end{array}$ \\
\hline Servant & $65 \%$ & $44 \%$ & $52 \%$ & $161 \%$ \\
\hline Transformational & $21 \%$ & $26 \%$ & $10 \%$ & $57 \%$ \\
\hline Situational/Contingency & $5 \%$ & $9 \%$ & $24 \%$ & $38 \%$ \\
\hline Transactional & $0 \%$ & $2 \%$ & $0 \%$ & $2 \%$ \\
\hline Authoritarian & $0 \%$ & $2 \%$ & $0 \%$ & $2 \%$ \\
\hline Distributive & $7 \%$ & $7 \%$ & $0 \%$ & $14 \%$ \\
\hline Democratic & $2 \%$ & $9 \%$ & $14 \%$ & $25 \%$ \\
\hline $\mathbf{N =}$ & 57 & 43 & 42 & 142 \\
\hline
\end{tabular}

This finding was also consistent for the geographical context in that the larger professional development programs in the area (Educator Leadership Academy, Leadership Oklahoma) used servant leadership as one of their primary models. The model was consistent with the generally held view that educators serve students and the public, but the results also showed that HE-P identified with this theory at 52\%. This was higher than the HE-A group where only $44 \%$ identified servant leadership as their most used theory (transformational was ranked second by this group at $26 \%)$.

Significant source of exposure

When asked about the source of their most significant exposure to leadership theories, models, or styles, women were more likely to identify the formal classroom (37\%) than men (27\%). Both groups appeared to have been exposed to leadership in professional development settings, but men were slightly more likely to have been exposed through self-directed processes (34\%) than women $(27 \%)$.

Table 4: The most significant source of exposure to leadership theories

\begin{tabular}{|l|l|l|l|l|}
\hline \multicolumn{1}{|c|}{ Respondents } & $\begin{array}{c}\text { Formal } \\
\text { Classroom }\end{array}$ & $\begin{array}{c}\text { Professional } \\
\text { Development }\end{array}$ & Self-Directed & Total \\
\hline K-12 & $35 \%$ & $35 \%$ & $30 \%$ & $\mathbf{5 7}$ \\
\hline HE-A & $26 \%$ & $42 \%$ & $33 \%$ & $\mathbf{4 3}$ \\
\hline HE-P & $38 \%$ & $33 \%$ & $29 \%$ & $\mathbf{4 2}$ \\
\hline Total & & & $\mathbf{1 4 2}$ \\
\hline
\end{tabular}

K-12 leaders responded in equal numbers and percentages (35\% in both areas) that their most significant source of learning about leadership was in the formal classroom as it was in professional development settings. Slightly fewer (30\%), who identified self-directed learning as their most significant source of learning. Nationwide, requirements for K-12 certifications and recertification were dynamic and complicated because of the changed K-12 landscape. These requirements included professional development portfolios that included safety training, diversity and culture 
awareness, technology, conference attendance, and district or state requirements to demonstrate skills and knowledge for leadership positions.

The results were similar for HE-P with these participants identifying a slightly higher level of experience in the formal classroom (38\%), followed by professional development (33\%) and then self-directed (28\%). The lack of prescribed professional development standards for professionals in higher education is not uncommon, nor is it uncommon to find that higher education experience in the form of a Master's degree is often sought in recruitment and requirements for leadership positions regardless of the field. Torpey and Terrell (2015), and the United States Bureau of Labor Statistics (2018), identified more than 30 occupations that typically required a master's degree for entry-level jobs, including education administrators at the elementary, secondary, and postsecondary levels. The bureau's data from selected education occupations indicated $46 \%$ of education administrators had a master's degree. The bureau's Occupational Outlook Handbook (2018) indicated postsecondary administrators typically needed at least a master's degree while provosts and deans were often required to have a terminal degree.

Academic leadership in HE are less likely to have had formal classroom exposure to leadership (only 25\%), than either of the other groups. They identified professional development as their most significant form of leadership development (41\%) and self-directed (32\%) as their second source. This finding does appear consistent with the more common career path of those in academic leadership "coming up" through the faculty to a chair or dean position and then to a Vice-President or Provost. Career paths should not automatically be interpreted as being a negative, though there is perhaps an irony in that leaders in academics are less likely to have had formal academic work in the area of leadership than their counter-parts in HE-P or K-12.

\section{Where do participants want to learn more?}

Participants were asked to identify two of the theories about which they wanted to learn more and gain a better understanding. Across the three primary perspectives, the greatest interest was in getting a better understanding of transformational leadership. In both the K-12 and the HE-P group the percentage of those expressing interest was more than $30 \%$. The HE-A group had $28 \%$ respond with an interest in transformational leadership and in distributive as well. The second choice was at least $8 \%$ points below the first choice.

The second and third area of interest for the K-12 group was situational/contingency (22\%) followed by distributive (16\%). The HE-P group reversed that order with distributive coming in second $(24 \%)$ and situational/contingency third (20\%). The third choice for the HE-A group was situational/contingency (17\%). All three groups identified the same three theories that they wanted

to understand better, but the overall most frequently identified theory for further study was the transformational leader. 
Table 5: Which of the leadership theories do you wish you understood better?

\begin{tabular}{|l|c|c|c|c|}
\hline & K-12 & HE-A & HE-P & Total \\
\hline Servant & $10 \%$ & $7 \%$ & $11 \%$ & $28 \%$ \\
\hline Transformational & $31 \%$ & $28 \%$ & $32 \%$ & $91 \%$ \\
\hline Situational/Contingency & $22 \%$ & $17 \%$ & $20 \%$ & $59 \%$ \\
\hline Transactional & $14 \%$ & $14 \%$ & $4 \%$ & $32 \%$ \\
\hline Authoritarian & $3 \%$ & $1 \%$ & $3 \%$ & $7 \%$ \\
\hline Distributive & $16 \%$ & $28 \%$ & $24 \%$ & $68 \%$ \\
\hline Democratic & $4 \%$ & $4 \%$ & $8 \%$ & $16 \%$ \\
\hline \multicolumn{1}{|c|}{$\mathbf{N}=$} & 106 & 81 & 76 & 263 \\
\hline
\end{tabular}

The transformational leadership theory was identified by women as the model they most wanted to learn more about (30\%) as well as the men (31\%). Distributive and situational/contingency followed as the second, and the third area of interest with only slight differences.

\section{Discussion}

The similarities and differences between the three groups were expected in some respects and completely unanticipated in others. K-12 has, for a long time, required that its professional leaders be certified, which required formal education. K-12 also has required and has provided continuing professional education of its teachers, and leaders, on an annual basis, certainly within the State of Oklahoma and also throughout much of the United States.

Those in Higher Education working outside of academics, HE-P, are not as well-defined a group ranging from those working in accounting areas, to student affairs, to any area outside of academics. That they would have developed their professional acumen in formal education is not surprising. Academic leaders, HE-A, on the other hand, have developed their professional interests in an academic discipline. The HE-A group is far less likely, by at least $10 \%$, in this study, to have had formal education as a primary source of leadership development, and they therefore are more dependent upon professional development and self-directed learning for that exposure. Whether this is a strength or a weakness or a limitation would be an area for further research.

The connection to existing leadership theories, either as a foundation for practice or a source of interest for future growth, was an unknown for the researchers and is one that may have implications for current teaching practice as well as development of future professional development programs. The dominant theory with servant leadership could be understood within both a contextual and a philosophical framework.

As indicated earlier, many of the professional development programs in Oklahoma, both for educators as well as professionals, use servant leadership as a foundational framework. It has been a popular model since its inception. Certainly, in this study, the philosophy of helping others to learn has a greater appeal to many in the field of education. Financial reward is generally not considered a motivating factor for those in the profession, regardless of the grouping. As Parker 
Palmer suggests in The Courage to Teach (1998), "Many of us became teachers for reasons of the heart, animated by a passion for some subject and for helping people learn" (Palmer, p.17).

The responses from all three leadership groups regarding their interest in learning more about a particular theory, model, or style or two, may well be understood within the context of the times and perhaps within the "jargon of the day." While there was variation, the number one interest was in transformational theory. In an era of change, and education certainly appears to be in turbulent times, it seems logical that leaders might want to learn more about that theoretical framework. Also, much like the servant leadership model being popular, the term "transformational" appears to have made it into mainstream language including the arena of television and YouTube commercials.

That HE-As tied between transformational and distributive could be a sign of the traditional approach of shared governance. Regardless of the interpretation, the ability to guide leadership development and formal experiences towards transformational leadership understanding would be useful to faculty and program planners, perhaps part of an on-going needs assessment model for leadership development.

\section{Implications for Future Research}

This study resulted in implications for future research. It was interesting to contrast the different forms of leadership development by each of the three groups in this study. Future research could determine which forms of leadership development are desired to determine the quality of the leaders. It could also be valuable to discover if educational leaders who are considered successful, identify with some theory model/style, or if these leaders are successful with no theoretical framework other than their own experience.

The different forms of professional development also suggest the difference in practice. The leaders in these three groups are unfamiliar with each other in terms of formal leadership development, though they may encounter each other in professional development workshops and conferences, though those meetings are, more often than not, segregated experiences. Future research could discover if there are benefits in the collaboration between HE-A and HE-P and K12 in the formal preparation process.

\section{Conclusion}

One of the most surprising findings revealed through this study was the theory identified as used most often in this study was servant leadership (Greenleaf, 1977) regardless of gender or leadership area (K-12, HE-A, HE-P). This finding was intriguing, as it shared the need for future research as to how these leaders used servant leadership (Greenleaf, 1997) in their daily leadership practice. Leaders' perceptions of servant leadership (Greenleaf, 1997) and their actual leadership practices should be examined for deeper clarification of their service.

Another intriguing finding included in this study was the participants' number one interest in learning about a particular theory or two, was transformational theory. With the call for educational leadership reform in K-12, and Higher Education working to improve student retention 
and increase enrollment numbers, transformational leadership and learning is a "new" theory that is piquing the curiosity of many leaders.

In terms of HE leadership development and K-12 leadership development in this study, indicated that there is a significant difference. As data were analyzed, results became clear that HE-A leadership was less likely to have had formal classroom exposure to leadership theories, models, and practices than HE-P and K-12 leaders. Leaders in academics are not as likely to have had formal leadership academic work. Higher Education Academics typically begin their leadership in $\mathrm{HE}$ as a professor in their academic field, proceed to program coordinator, department chair, and then branch out into various leadership roles such as deans, directors, or vice-presidents.

Although there is a paucity of research on leadership development in higher education, the research presented supports the need for more research in the area of professional development for HE-A, and HE-P, and K-12. Improved practices in K-12 and Higher Education leadership could be the needed change that makes effective professional development an integral part of leadership improvement and practice by expanding the knowledge base on the need for high quality leadership development in educational leadership reform. Organizational leadership programs could include all levels of educational leaders to enhance leadership knowledge.

\section{References}

Amey, M. J. (2006). Leadership in higher education. Change: The Magazine of Higher Learning, 38(6), 55-58.

Avolio, B. (1999). Full leadership development: Building the vital forces in organizations. Sage.

Bacheler, M. (2015). Professional development of continuing higher education unit leaders: A need for a competency-based approach. The Journal of Continuing Higher Education, 63, 152-164.

Barnett, B., Hall, G., Berg, J., and Camarena, M. (1999). A typology of partnerships for promoting innovation. Journal of School Leadership, 9(6), 484-510.

Bass, B. (1997). Does the transactional-transformational leadership paradigm transcend organizational and national boundaries? American Psychologist, 52(2), 130-139.

Bass, B., Avolio, B., Jung, D., \& Berson, Y. (2003). Predicting unit performance by assessing transformational and transactional leadership. Journal of Applied Psychology, 88(2), 207-218. Retrieved from http://dx.doi.org/10.1037/0021-9010.88.2.207

Bass, B. \& Bass, R. (2008). The Bass handbook of leadership: Theory, research, and managerial applications. Free Press.

Bass, B. (1998). Transformational leadership: Industrial, military, and educational impact. Erlbaum.

Bennis, W. (1995a). The art form of leadership. In T. Wren (Ed.), The leader's companion: Insights on leadership through the ages (pp. 377-378). Free Press.

Bennis, W. (1995b). The four competencies of leadership. In D.A. Kolb, J.S. Osland, \& I.M. Rubin (Eds.), The organizational behavior reader (pp. 395-401). Prentice Hall.

Bisbee, D. (2007). Looking for leaders: Current practices in leadership identification in higher education. Planning and Changing, 38(1\&2), 77-88.

Black, W., Martin, G., \& Danzig, A. (2014). Pathways for performance: Research on recruitment and selection, university preparation, licensure, and professional development for school principals. Educational Leadership Review, 15(2), 1-13.

Bogler, R. (2001). The influence of leadership style on teacher job satisfaction. Educational Administration Quarterly, 37(5), 662-683. Retrieved from https://doi.org/10.1177/00131610121969460

Bolman, L. G., \& Deal, T. E. (2003). Reframing organizations: Artistry, choice, and leadership ( $4^{\text {th }}$ ed. $)$. Jossey-Bass.

Bowers, D. G. (1997). Systems of organization: Management of human resources. University of Michigan Press.

Burns, J. (1978). Leadership. Harper and Row. 
Burns, J. (2003). Transforming leadership: A new pursuit of happiness. Atlantic Monthly Press.

Bureau of Labor Statistics (2018). Occupational outlook handbook, postsecondary education administrators. U.S. Department of Labor. Retrieved from https://www.bls.gov/ooh/management/postsecondary-educationadministrators.htm

Bustamante, R. M. \& Combs, J. P. (2011). Research courses in education leadership programs: Relevance in an era of accountability. International Journal of Education Policy and Leadership 6(3). Retrieved from http://www.ijepl.org

Collins, J. (2001). Good to great. Harper Collins Publishers, Inc.

Covey, S. R. (1989). The 7 habits of highly effective people. Simon \& Schuster.

Covey, S. R. (2013). The 7 habits of highly effective people: Powerful lessons in personal change. Simon \& Schuster.

Davis, S., Darling-Hammond, L., LaPointe, M., \& Meyerson, D. (2005). School leadership study developing successful school principals. Stanford Educational Leadership Institute (SELI): Stanford, CA. citeseerx.ist.psu.edu/viewdoc/download?doi=10.1.123.7780\&rep=repl\&type=pdf

Decker, S. (1989). The relationship among principal power tactic usage, leadership style and school climate in selected Iowa elementary schools (Unpublished doctoral dissertation.) University of Northern Iowa, Cedar Falls.

DiPaola, M., \& Hoy, W. (2005). Organizational citizenship of faculty and achievement of high school students. The High School Journal, 88(3), 35-44.

DiPaola, M., \& Tschannen-Moran, M. (2001). Organizational citizenship behavior in schools and its relationship to school climate. Journal of School Leadership, 11, 424-447.

Drucker, P. (1988). The coming of the new organization. Harvard Business Review, 66, 45-53.

Dufour, R., Dufour, R., Eaker, R., \& Many, T. (2006). Learning by doing: A handbook for professional learning communities at work. Solution Tree.

Dufour, R., \& Eaker, R. L. (1998). Professional learning communities at work: Best practices for enhancing student achievement. National Education Service.

Ely, R. (1994). The effects of organizational demographics and social identity on relationships among professional women. Administrative Science Quarterly, 39, 203-238.

Fullan, M. G. (1993). Change forces. Falmer Press.

Fullan, M. G. (1999). Change forces: The sequel. Routledge.

Fullan, M. G. (2002). The change leader. Educational Leadership, 59(8), 16-20.

Gall, M., Borg, W., \& Gall, J. (1996). Educational research: An introduction (6th ed.). Longman Publishing.

Gardner, J. (1993). On leadership. Free Press.

Geijsel F., Sleegers P., \& Van den Berg, R. (2002). Conditions fostering educational change. In Leithwood K., et al. (eds.), Second International Handbook of Educational Leadership and Administration. Springer International Handbooks of Education, 8. Springer, Dordrecht.

Gigliotti, R., \& Ruben, B. (2017). Preparing higher education leaders: a conceptual, strategic, and operational approach. Journal of Leadership Education. doi: 10.12806/V16/11/T1, 96-114

Gmelch, W. (2000). Leadership succession: How new deans take charge and learn the job. Journal of Leadership and Organizational Studies, 7(3), 68-88. Retrieved from https://doi.org/10.1177/107179190000700305

Gmelch, W., \& Buller, J. (2015). Building academic leadership capacity: A guide to best practices. Jossey-Bass.

Green, R. (2017). Practicing the art of leadership: A problem-based approach to implementing the professional standards for educational leaders. Pearson.

Greenleaf, R. K. (1977). Servant leadership: A journey into the nature of legitimate power and greatness. Paulist Press.

Greenleaf, R. K. (1997). The servant as leader. In R. P. Vecchio (Ed.), Leadership: Understanding the dynamics of power and influence in organizations (pp. 429-438). University of Notre Dame Press. (Reprinted from "Servant Leadership," Paulist Press, 1977, pp. 7-17).

Halpin, A. W. (1966). Theory and research in administration. Macmillan.

Jackson, N. (1996). Internal academic quality audit in UK higher education: Part I - current practice and conceptual frameworks. Quality Assurance in Education, 4(4), 37-46. Retrieved from https://doi.org/10.1108/09684889610146181

Kezar, A., and Holcombe, E. (2017). Shared leadership in higher education: Important lessons from research and practice. American Council on Education.

Kotter, J. (2001). What leaders really do. Harvard Business Review, 79, 85-98.

Lashway, L. (1999). Preparing school leaders: Research roundup. NAESP, 15(3), 1-4. 
Lezett, L. (1997). Learning for all. Okemos, MI: Effective School Products.

Leithwood, K. (1992). The move toward transformational leadership. Educational Leadership, 49(5), 8-12.

Leithwood, L., \& Jantzi, D. (2006). Transformational school leadership for large-scale reform: Effects on students, teachers, and their classroom practices, School Effectiveness and School Improvement, 17(2), 201-227. doi: $10.1080 / 09243450600565829$

Leithwood, K., Menzies, K., Jantzi, D., \& Leithwood, J. (1996). School restructuring, transformational leadership and the amelioration of teacher burnout. Anxiety, Stress and Coping: An International Journal, 9(3), 199215. Retrieved from https://doi.org/10.1080/10615809608249402

MacKenzie, S., Podsakoff, P., \& Rich, G. (1987) Higher education leadership: Enhancing skills through professional development programs. Journal of the Academy of Marketing Science, 29(2), 115-134.

Manz, C. C., \& Sims, H. P., Jr. (1989). Superleadership. Berkley.

March, J., \& Weil, T. (2005). On leadership. Blackwell Publishing.

Marzano, R. J., Waters, T., \& McNulty, B. A. (2005). School leadership that works: From research to results. Association for Supervision and Curriculum Development.

Metheney-Fisher, L. (2012). Learning to lead: How leaders in higher education learn to lead. (Doctoral dissertation). University of Oklahoma Graduate College.

Miller, D. (2001). Successful change leaders: What makes them? What do they do that is different? Journal of Change Management, 2(4), 359-368. doi: 10.1080/714042515

Nicoll, K., \& Edwards, R. (2012). Positioning adult educators in discourses of professional development. Studies in Continuing Education, 34(3), 233-249.

Northouse, P. (2015). Introduction to leadership: Concepts and practice. Thousand Oaks, CA: Sage Publications.

Palmer, P. (1998). The courage to teach. Jossey-Bass.

Pont, B., Nusche, D., \& Moorman, H. (2008). Improving School Leadership Volume 1: Policy and Practice (Report No. 1). Retrieved from Organization for Economic Cooperation \& Development (OECD) website www.oecd.org/education/school/44374889.pdf

Pounder, D., Ogawa, R., \& Adams, A. (1995). Leadership as an organization-wide phenomenon: Its impact on school performance. Educational Administration Quarterly, 31(4), 564-588. Retrieved from https://doi.org/10.1177/0013161X9503100404

Reeves, D. (2006). Leading to change: How do you change school culture? Science in the Spotlight, 64(4), 92-94.

Reeves, P., \& Berry, J. (2009). Preparing, developing, and credentialing K-12 school leaders: Continuous learning for professional roles. OpenStax-CNX Version 1.2, National Council of Professor of Educational Administration. Retrieved from https://cnx.org/contents/TTYki8RO@2/Preparing-Developing-andCredentialing-K-12-School-Leaders-Continuous-Learning-for-Professional-Roles

Rossman, G. (1999). Designing Qualitative Research. Sage.

Ruben, B. (2004). Pursuing excellence in higher education: Eight fundamental principles. Jossey-Bass.

Ruben, B., De Lisi, R., \& Gigliotti, R. A. (2017). A guide for leaders in higher education: Core concepts, competencies, and tools. Stylus.

Senge, P. M. (2006). The fifth discipline: The art and practice of the learning organization (Rev. Ed.). New York, NY: Doubleday.

Sergiovanni, T. J. (1994). Building community in schools. Jossey-Bass.

Sergiovanni, T. J. (1996). Moral leadership: Getting to the heart of school improvement. Jossey-Bass.

Sessa, V., \& Taylor, J. (2000). Choosing leaders: More cooks make a better broth. Consulting Psychology Journal: Practice and Research, 52(3), 218-225. Retrieved from http://dx.doi.org/10.1037/1061-4087.52.3.218

Spillane, J. (2005). Distributed leadership. The Educational Forum. Retrieved from www.findarticles.com/p/articles/mi_Qa4013/is_200501/ai_n9473825

Torpey, E., \& Terrell, D. (2015). Career outlook: Should I get a master's degree? United States Department of Labor, Bureau of Labor Statistics, September 2015. Retrieved from https://www.bls.gov/careeroutlook/2015/article/should-i-get-a-masters-degree.htm\#Masters\%20box

Wallace Foundation (2013). The school principal as leader: Guiding schools to better teaching and learning. Perspective (Expanded ed.).

Yukl, G. (1989). Managerial leadership: A review of theory and research. Journal of Management,15(2), 251-289.

Yukl, G. (2008). How leaders influence organizational effectiveness. The Leadership Quarterly, 19, 708-722. Retrieved from http://dx.doi.org/10.1016/j.leaqua.2008.09.008 


\section{Appendix A}

\section{Survey}

1. What is your gender?

- Male

- Female

- Prefer not to answer

2. Which best describes your position?

- K-12 Administration

- Higher Education Academic Administration

- Higher Education Administration (Non-Academic)

3. Rank the top three leadership theories that you use the most.

- Servant

- Transformational

- Situational/Contingency

- Transactional

- Authoritative/Autocratic

- Distributive

- Democratic

- Other- fill in the blank box

4. Which two theories below do you wish you had a better understanding of?

- Servant

- Transformational

- Situational/Contingency

- Transactional

- Authoritative

- Distributive

- Democratic/Autocratic

- Other- fill in the blank box

5. What was the most significant source for your exposure to leadership theories?

- Formal Classroom

- Professional Development (seminars, workshops, etc.)

- Self-Directed (Reading, Social Media, etc.) 


\section{Appendix B}

\begin{tabular}{|l|l|l|}
\hline \multicolumn{1}{|c|}{ Theories } & \multicolumn{1}{|c|}{ Founder(s) } & \multicolumn{1}{c|}{ Definition(s) } \\
\hline Transformational & $\begin{array}{l}\text { Downtown, James } \\
\text { MacGregor Burns }\end{array}$ & $\begin{array}{l}\text { Leadership that effects change in an } \\
\text { organization and is an engagement } \\
\text { between followers \& leaders. }\end{array}$ \\
\hline Servant & Greenleaf & $\begin{array}{l}\text { Leaders focus on their followers' } \\
\text { needs in order to help these } \\
\text { followers become more } \\
\text { autonomous, knowledgeable, \& like } \\
\text { servants themselves. }\end{array}$ \\
\hline Transactional & $\begin{array}{l}\text { A style of leadership in which } \\
\text { leaders promote compliance by } \\
\text { followers through both rewards and } \\
\text { punishments. }\end{array}$ \\
\hline Authoritative/Autocratic & $\begin{array}{l}\text { Leaders perceive followers as } \\
\text { needing direction and emphasize } \\
\text { that they are in charge. }\end{array}$ \\
\hline Distributive & $\begin{array}{l}\text { Interactions among people generally } \\
\text { involve multiple leaders in both } \\
\text { formal \& informal roles. }\end{array}$ \\
\hline Democratic & Spillane & $\begin{array}{l}\text { Group members take a more } \\
\text { participative role in decision- } \\
\text { making and is shared leadership. }\end{array}$ \\
\hline Hershey and & $\begin{array}{l}\text { The choice of leadership style, or } \\
\text { leader, depends on the situation and } \\
\text { organizational conditions. }\end{array}$ \\
\hline
\end{tabular}

